Sveučilište u Zagrebu

\title{
The Therapeutic Function of Metaphor: the Case of Emotions in the Croatian Public Discourse
}

\begin{abstract}
Stanojević Mateusz-Milan, Čičin-Šain Višnja, The Therapeutic Function of Metaphor: the Case of Emotions in the Croatian Public Discourse. "Poznańskie Studia Slawistyczne" 9. Poznan 2015. Publishing House of the Poznań Society for the Advancement of the Arts and Sciences, pp. 91-108. ISSN 2084-3011.

In this paper we (re-)examine the role of deliberate metaphors in the public discourse. Based on an analysis of metaphorical comments to the articles reporting on a dispute between the Croatian Prime Minister and Minister of Finance, we argue that in addition to a number of established discursive functions, metaphor may perform a therapeutic function aiding commenters in working through their emotions. Our analyses of the course that comments take shows that they are not structured according to a usual turn-taking logic, but rather on the basis of the coherence of the emotions shared by the commenters. Moreover, the tripartite internal structure of the comments (identifying the critical event, running the blend, possibly offering a solution to the critical event) is aimed at symbolically delegitimizing politicians, putting the author in charge of the experience, thus enabling him/her to work through it. Theoretically, such a view suggests that on the discourse level it is not necessarily metaphor that is used as the structuring device, but that emotion can structure metaphor.
\end{abstract}

KeYwords: deliberate metaphor; emotions; political discourse; Croatia; comments section of online newspapers; therapeutic function of metaphor

\section{Introduction}

Discourse-oriented studies looking into the role of conceptual metaphor in use have shown that in addition to its cognitive function, which has been emphasized as primary by "classical" conceptual metaphor theory (CMT) studies (cf. e.g. Lakoff, Johnson 1980; Lakoff 1993; Kövecses 
2000), metaphor plays an important sociocultural role. Metaphors, as used in discourse, may be founded on basic level concepts but they employ the basic-level knowledge in various ways; moreover they evolve in social interaction, and are rooted in the cultural and discursive reality (Zinken, Hellsten, Nerlich 2008: 374). This means that metaphors are often contested, used as an ideological tool, and co-constructed (for an overview cf. Šarić 2014), particularly in public discourse. For instance, in a stretch of discourse such as (1) (which appears in the online comments section of an article in "24 sata", a Croatian daily newspaper), the commenter rejects the metaphor whereby the conflict between the former Croatian Finance Minister and the Prime Minister is referred to as a gunfight in the dominant discourse, and proposes a different metaphor:

(1) Mnogi grě̌e ovo nije obračun, Ovo je posljedni pokušaj brice da od g-e napravi li-e.Ovaj rejting što ga imaju nisu ga zaslužili,to je i previše.

'Many are mistaken, this isn't a gunfight. This is the barber's last attempt to make a face out of an ass. The rating they've got - they haven't deserved it, it's much too high'.

The situation is not a gunfight but "the barber's last attempt to make a face out of an ass", which is a conventional expression referring to a futile last attempt to do something. Intertextually, the metaphor belongs to the political public discourse, because it explicitly refers to the dominant metaphor. However, the commenter is not a stakeholder in the political discussion, and it is difficult to say that his/her statement will become part of the same metaphorical power struggle or persuasive political discourse (e.g. Musolff 2004; Koller 2005; Charteris-Black 2011) as that of the "more powerful" participants (such as politicians or journalists). Other commenters of the same article do not seem to take notice of this or the other comments. Therefore, although it appears in the public discourse, this metaphor does not seem to be dialogual in the same sense as contested metaphors seem to be in a public political debate: the metaphors we are referring to do not present opposing arguments, via turn taking or in other ways (cf. Traugott 2008). So, if it is not dialogual, what is it?

${ }^{1}$ The comments appear exactly as they do in the source. All translations are ours. $<$ http://www.24sata.hr/komentari/poceo-dvorski-obracun-milanovic-napao-linica-365253>, 19.05.2014. 
In this paper, we claim that examples such as (1), which are a reaction to an emotionally charged critical event in the public sphere, serve a therapeutic function: they aid the commenters in working through the (negative) emotion, taking charge of the situation and expressing their dissatisfaction. These metaphors are deliberate (Steen 2014) and non-dialogual: their discourse coherence depends on their emotive charge rather than their conceptual content. Theoretically, such a view suggests that on the discourse level it is not necessarily metaphor that is used as the structuring device, but that emotion can structure metaphor.

In the following section, we present a short theoretical overview of the functions of discursive metaphor. In section 3, we look into the non-dialogual nature of metaphor and its therapeutic function in online newspapers comments. The paper ends with a discussion and conclusion.

\section{Metaphor and emotion in the online comments}

The function of conceptual metaphor in a variety of "classical" CMT approaches is seen as organizational: conceptual metaphor is claimed to structure our knowledge. For example, it has been asserted by Kövecses (2000) that metaphor organizes the way we conceptualize emotions. More recently, it has been shown that the structuring of emotion concepts is a more dynamic process, where metaphorical and non-metaphorical reasoning work together, influencing each other (Kövecses 2012). Moreover, other forces may also be at stake, including, e.g. diachronic development (Geeraerts, Gevaert, Speelman 2011), or grammar (Stanojević, Ljubičić, Tralić 2014).

In this way, CMT has been drawing closer to a view where it is not only the conceptual content that is involved in metaphor use, but also intersubjective, social content, as abundantly shown in a variety of discourse-based studies (cf. e.g. Zinken, Hellsten, Nerlich 2008; Zinken, Musolff 2009). Our reasoning and discursive practices - metaphor included - are intersubjective (Verhagen 2005), i.e. shaped "by being together with other embodied minds" (Frank 2008: 1).

In political discourse, metaphorical expressions are often used as persuasive tools (Charteris-Black 2011) in a power struggle between discourse participants: they may function as an ideological, strategic means, 
whose sole purpose is to deceive or convince other discourse participants "covertly communicating ideology" (Hart 2010: 128), force fear appeals and/or perform other mystifying, propagandist functions (Cap 2013).

In other, less public, but still co-constructed discourses, metaphors have also been shown to be used interactionally. For instance, in the classroom discourse they are reformulated, repeated, and tuned, keeping in mind the expectations and needs of the collocutors (Cameron 2003), and in a foreign language classroom they may be used in a relationship-building function, e.g. as language play (Littlemore, Low 2006: 129-132).

Metaphors may also serve as a way of mediating one's emotional experience to others, e.g. mitigating potential threats to one's collocutors in a classroom discourse (Cameron 2003). The mediation, moreover, may also be a way of trying to make sense of one's own emotional experience or a critical event (Delfino, Manca 2007). For instance, cancer patients use metaphors to talk about their illness (Koller 2013; Semino 2014), and students in online learning environments use metaphors to mediate their emotions and learning difficulties in written online discourse (Delfino, Manca 2007; Cavalcanti, Bizon 2008). In this sense, we see emotions ${ }^{2}$ as situated: "emotions are not only expressive strategies, they are also negotiating strategies" (Griffiths, Scarantino 2009: 446-447).

Furthermore, metaphors used in the discourse, if meant "to change the addressee's perspective on the referent or the topic that is the target of metaphor", may be termed as deliberate (Steen 2008: 222). Deliberate metaphors are communicational: their deliberateness need not be connected with linguistic or conceptual novelty (Cameron 2003: 101), but is a function of the intentions behind their use. Blending (Fauconnier, Turner 2003) is crucial in deliberate metaphors, being particularly suitable for discourse analysis (Hart 2008), as it deals with online meaning construction, and allows combinations of various unrelated metaphorical and non-metaphorical scenarios.

It is no coincidence therefore that situated emotions and deliberate metaphors appear in online comments. Due to their nature and purpose of giving the public a place to express their opinion, they tend to be the section where emotive discourse most commonly flourishes in online

${ }^{2}$ Following Wilce (2009), the terms "emotion" and "emotional" will be adopted as umbrella terms for what psychologists usually refer to as emotion, affect and attitude. 
newspapers. As Henrich and Holmes notice, "Comments yield real-time insights into public attitudes on issues (...). These comments and responses serve as a gauge of public opinion that is immediate, spontaneous and (presumably) honest" (Henrich, Holmes 2013: 2; emphasis added M.M.S., V.Č.-Š.), and they serve as a valuable means of "diverse and authentic public deliberation" (Manosevitch, Walker 2009: 5).

The question that arises from this short theoretical overview concerns the function of metaphor in the online comments to newspaper articles. On the one hand, it would be reasonable to expect commenters to question dominant metaphors in an attempt to present their own views of the political situation at hand. On the other, since they are not political stakeholders, they might engage in discussion with the other commenters, reworking and negotiating their metaphors; because the other commenters might be willing to engage in discussion. Finally, the high emotional charge of the public events that are commented on and the fact that comments are not primarily designed for turn taking (as are, e.g., online forums) might bring other issues to the fore. In what follows we will attempt to examine these views by means of two analyses of the online comments found in Croatian newspapers.

\section{The therapeutic function of metaphor: analyses}

\subsection{Background}

In order to find examples of emotion-laden deliberate metaphors we looked through a number of Croatian online newspapers, searching for articles dealing with the conflict between the former Minister of Finance, Slavko Linić, and the current Prime Minister Zoran Milanović. For this paper we selected a number of comments from "Večernji list" and "24 sata", focusing particularly on those containing deliberate metaphors (identified by intuition). All the metaphorical instances have been created at a tumultuous period in the Croatian Government, wrought with instability and what was generally seen as unsuccessful political leadership ${ }^{3}$. The sudden

${ }^{3}$ In June 2014, according to the CROBAROMETAR poll conducted by IPSOS PULS Centre for Public Opinion Research, so much as $83 \%$ of the Croatian citizens were unsatisfied 
surge of public disputes and accusations between Milanović and Linić was met with strong disapproval in the public. Accordingly, the metaphorical expressions chosen from the comments section of the articles reporting on the dispute between the two political "titans" reflect a general outburst of more or less serious criticism and annoyance provoked by both the general political situation in the country, and more specifically, their tactless public quarrel.

We have opted for a small-scale qualitative study. In the first part of the analysis, we examine comments that appear in relation to a single lead article in " 24 sata", looking for the ways in which the commenters engage the dominant metaphors present in the lead article as well as each other. In the second part, we look into the structure of a number of metaphorical comments regarding the topic from both "24 sata" and "Večernji list". Based on this, we argue for the therapeutic function of metaphor.

\subsection{Emotions structure metaphor}

The comments reported in this section appear in the comments section to a video clip ${ }^{4}$ featuring several observations by the political analyst Žarko Puhovski. The textual introduction above the clip features Puhovski's explanation where the dispute between the Prime Minister and the former Minister of Finance is likened to a conflict at the court. The commentary was given impetus by a story (concerning the former Minister's of Finance alleged involvement in embezzlement) that appeared in a rival newspaper, the "Jutarnji list". According to Puhovski, Milanović was determined to dispose of his Minister of Finance since, in stark contrast to him, Linić was highly popular at the time, which was allegedly an unusual state of affairs in politics. A variety of metaphorical expressions appear in the video clip

with the manner in which the state had been run by the ruling coalition by then. Reported by Nova TV news, 25.06.2014 < http://dnevnik.hr/vijesti/hrvatska/crobarometar-ekskluzivnotko-je-gubitnik-a-tko-dobitnik-lipnja---341635.html>, 9.08.2014.

${ }^{4}$ Počeo dvorski obračun: Milanović napao Linića, "24 sata" 5.05.2014; video clip: $<$ http://www.24sata.hr/politika/poceo-dvorski-obracun-milanovic-napao-linica-365253>, 9.08.2014. Comments section:< http://www.24sata.hr/komentari/poceo-dvorski-obracunmilanovic-napao-linica-365253>, 9.08.2014. 
(to give one's head on a platter, to air dirty laundry in public, to be a patient etc., all related to the conflict between the two politicians), some of which were later taken up in the 23 comments and several replies below.

The comments in this thread do not take a clear turn-taking structure. Except in a single case ${ }^{5}$, the comments do not refer to other comments, and only two contain replies, one of which is non-metaphorical, and one metaphorical (with a question by a puzzled reader about how to reconstruct the metaphor). This is in line with the affordances ${ }^{6}$ of the comment function in the "24 sata" newspaper: by default, comments are organized by popularity rating rather than by when they were written. This means that their order of appearance is easily lost, which is not conducive to the conceptual coherence expected in turn taking. The reply function seems to be rarely used ${ }^{7}$.

The same is true of metaphorical comments illustrated below. This suggests that, albeit, conceptually loosely motivated by the metaphorical language used in the article (video clip), with respect to one another, metaphorical comments are conceptually heterogeneous, self-contained units whose principal purpose is neither that of replying to other commenters' metaphors nor that of initiating a dialogue with the other readers/commenters. What clearly makes them a coherent unity on the discourse level, though, is the common emotional component, i.e. the discontent/indignation caused by the futility that they identify in the actions of politicians.

For instance, in (2) the commenter points out that the damage arising from the dispute between Milanović and Linić will have no bearing whatsoever on the actors involved in the conflict (members of the party in power) since, to his/her mind, it is the people who will pay and in fact have paid, with interest.

(2) Šteta je nanesena i to državi,nebitno za SDP oni će se oporaviti,žrtvom par piuna i pokojeg topa.AL kralj ostaje,priznaće pat i partija gotova,Ko će to platiti,narod je već platijo, i plaćeno vraća s kamatama.Doli Kralj.

${ }^{5}$ One commenter makes reference to the gunfight metaphor that has been earlier used and elaborated by another commenter.

${ }^{6}$ We side with Hampel (2006: 11) who defines affordances as "the constraints and possibilities for making meaning".

${ }^{7}$ It seems that the only feedback the comments receive is through the rating feature, but note that this is also a clear way of expressing one's judgment of the situation (i.e. emotions). 
'This is damaging to the state, it has no bearing on the SDP, they will recover sacrificing a couple of pawns and a rook or two. But the king remains, he'll admit stalemate and the game is over. Who will pay for this? The people have already paid and they have paid it off with interest. Down with the King'.

In order to work through this critical event, the commenter elaborates on the conceptual metaphor politics is a game of chess. Thus, the Social Democratic Party, one of the parties in the game of chess (it is unclear who the other party would be), will sacrifice a couple of insignificant chessmen in order for the king to remain standing, admit stalemate, ending the game. This sacrifice, which should work according to the moral accounting metaphor (Johnson 1993: 45) - i.e. should entail tangible consequences for politicians - in essence does not result in any significant repercussions for them. Thus, the chess game is presented as a single episode, and the fact that the king remains standing (as it does at the end of a chess game, be it stalemate or checkmate) leads to the possibility of a new game. The situation will not be set right (according to the moral accounting scenario) until the king is gone (as seen in the last sentence, "down with the king").

The comment is an attempt to work through the futility of political episodes of conflict which do not result in an improvement of the overall situation. These episodes resemble chess, but they are played according to a different logic. It is not until this logic is overturned that the real culprits will suffer the consequences of the situation. Since the notion of accountability is not part of the knowledge about chess, the author resoundingly rejects the metaphor, which presents his/her personal act of working through the problem.

Similarly, in (3) the commenter attempts to work through improper conduct by politicians:

(3) Budući smo postali Divlji zapad, a jesmo, logično je da imamo i svoj Obračun kod OK Corrala, i to na relaciji Zagreb-Rijeka.Tko je u klanu Wyatta Earpa i Doc Hollidaya a tko na drugoj strani u klanu Clanton uskoro ćemo saznati. Upitno je tko će u tom klanovskom srazu biti pobjednik, ali svi znamo tko su vječni gubitnici...

'Since we became the Wild West, and we did, it is only logical that we have our gunfight at the O.K. Corral, and that we have it between Zagreb and Rijeka. We will soon find out who's in Wyatt Earp and Doc Holliday's clan and who's on the other side in the Clanton clan. It is uncertain who will be the winner in this conflict between the clans, but we all know who the eternal losers are...'. 
The commenter presents the conflict between Milanović and Linić (metonymically represented by Zagreb and Rijeka, where they enjoy their greatest political support) using the OK Corral scenario, perhaps prompted by Puhovski's label obračun (Croatian 'conflict' as well as 'gunfight'). Although is unclear who "the good guys" or "the bad guys" are (Wyatt Earp and Doc Holliday vs. the Clanton Clan) or who will win, the commenter poignantly points out that everyone knows who the eternal losers are.

Unlike the chess metaphor, the Wild West scenario bears connotations of savagery and brutality, taking the previously established negative tone one step further. The concluding remark continues the futility theme from the chess blend. Both commenters agree that the Croatian people are suffering the consequences of political negligence. Whatever the outcome of the game or the shootout, the citizens are those who are ultimately defeated. The author's metaphorical contribution supports and develops the emotional background constructed in the lead video and by the other commenters. The Wild West blend is a way in which the commenter sanctions the tone of the surrounding discourse and the symbolic delegitimization of the politicians' authority, thus taking charge of his/her experience and showing emotional solidarity with the other commenters.

The next commenter rejects the gunfight metaphor, at first seemingly rejecting the emotional flow and unity constructed throughout the comments. He/she says that "many are mistaken" thinking that what is happening between Milanović and Linić is a gunfight, only to "strike" even harder, employing a metaphor of court intrigues, clearly related to the use of dvorski obračun 'intrigues at the court' in the lead video.

(4) Jako su zanimljive ove dvorske spletke.Sudionicima stoji na raspolaganju otrov(imaju ga u ogromnim količinama), bodež,zli jezici,perfidne laži,đon (na cipeli), vlastita logika,grabež, Ustav (protumačen na njima svojstven način), Porezna uprava,porezi i drugi rekviziti.Zapamtite -tko je jači-taj kvači.

'These intrigues at the court are very interesting. At their disposal the participants have poison (they have it in huge amounts), dagger, evil tongues, vicious lies, sole (of the shoe), their own logic, plundering, the Constitution (interpreted in their own particular way), Tax Administration, taxes and other props. Remember - might overcomes right'.

The commenter blends court intrigues and the political situation in Croatia, listing the instruments that the two main participants have at their disposal for their intrigues. These include: items that may appear in the 
court intrigue scenario (such as poisons and daggers), items that are part of the negative view of the political situation in Croatia (lies, speaking ill of others, trampling on others, plundering) as well as things that are a legitimate part of everyday and political life (logic, the Constitution, taxes). The last group should ensure equal rights and opportunities, but is exploited by politicians to their own ends. The commenter concludes by saying that 'might overcomes right', i.e. that justice is nothing but the interest of the stronger, thereby implicitly condemning the morality of Croatian politicians. The improper conduct of the politicians points to the lack of justice in the state, which is precisely the burdensome experience that the commenter is trying to work through in the blends he/she creates. The futility of the situation is evident, this time without reference to a solution (as in the previous examples).

Our analysis of the non-metaphorical and metaphorical comments to a single article shows that although they may refer to the content appearing in the lead article, the commenters do not conceptually refer to each other's comments. Even when ingenious deliberate blends are used to refer to the situation, normally a prime target for negotiation and persuasion in the public discourse (Musolff 2004; Koller 2005; Charteris-Black 2011), they do not encourage further elaborations or negotiations. One reason for this may be the affordance of the comment feature, which is not conducive to dialogue. Nevertheless, unity is achieved on the emotional level in the metaphorical comments, all of which point to the futility of the situation in the country. Thus, the metaphors in the comments are primarily a means of interpreting the difficult situations to oneself, an attempt to work through and articulate one's own emotions, rather than a means of turn-taking ${ }^{8}$ communication.

\footnotetext{
${ }^{8}$ Note that the distinction we are making - metaphors being organized by their emotional rather than by their conceptual content - is reminiscent of Traugott's (2008) distinction between dialoguality and dialogicity. Dialoguality refers to turn-taking communication between participants, whereas dialogicity refers to the multiplicity of views presented. In this sense, therapeutic metaphor might, on the surface, be considered non-dialogual and dialogic. Still, if we view dialogicity on the emotive level (rather than on the conceptual differences in the blends), the emotive homogeneity of the views points to non-dialogicity.
} 


\subsection{The therapeutic facet of the comments}

We now turn to a more detailed analysis of the structure of single comments, which all exhibit a symbolic overturn of power as a way to work through the critical event, which is characteristic of the therapeutic function of metaphor. The following two stretches of discourse are both comments to articles which appeared in "Večernji list". The following is a comment to an interview with Slavko Linić 9 . In the interview, the former Minister speaks out about the Prime Minister's alleged involvement in corruption, accusing him of misusing a privileged position and nepotism.

(5) Problem je u kompletnom sustavu koji na svim slojevima ima mehanizme koji daju ovakve ishode, od vrha države do vrhova državnih i paradržavnih slojeva sve do gradova i udruga gradjana. Nikaj se ne mijenja na bolje, bolesnik je smrtno bolestan a izbori mu samo mijenjaju posteljinu i pidžame, malo crna, malo crvena, dugo plava, sad crvena i uskoro opet poznata plavo/crna. Sustav nevalja, brod tone a mi biramo izmedju nesposobnih posada. Treba izabrati vladu i predsjednika javnim medjunarodnim natječajem.

'The problem lies in the entire system that has mechanisms producing such outcomes on all the levels, from the top structures of the state across the highest levels of state-run and parastatal levels down to towns and non-governmental organizations. Nothing changes for the better, the patient is terminally ill and all that the elections change is his bed linen and pyjamas: black pyjamas for a while, then red ones, then blue ones for a long time, now red ones and, soon, familiar black and blue ones again. The system does not work, the ship is sinking and we get to choose between incompetent crews. The government and the president should be elected by an international tender'.

The beginning of the comment does not contain metaphorical language and serves as a contextual base for the blends that follow. It is here that the author identifies that the problem lies in the entire system, where nothing changes for the better. This is the exposition of the critical event.

What follows is a blend, based on the personification of the Croatian state as a terminally ill patient. The sickness scenario intensifies the negative affect overtly expressed in the introductory part of the comment and marks the beginning of working through the event.

${ }^{9}$ Milanović je morao znati što mu radi brat, da hoda po ministarstvima, vrši pritisak i posreduje, "Večernji list" 31.05.2014, <http://www.vecernji.hr/hrvatska/milanovic-je-morao-znati-sto-mu-radi-brat-da-hoda-po-ministarstvima-vrsi-pritisak-i-posreduje-942015>, 9.08.2014. 
The climax of the comment is presented next. In a situation where the patient-state in the blend is in critical condition, only bed linen and pyjamas are changed, which cannot influence the condition of the patient. The colours of the pyjamas and the bed linen are symbolic of the two main political parties in Croatia ${ }^{10}$. The change of colour represents the change of the political party in power, and should (because of the logic of the input space) mark profound political changes (right-wing vs. left-wing politics). However, the blend inherits the logic of the sickness scenario, whereby the change of colour will only make an insignificant change to a marginal action performed on the dying patient. The blend implies that the process of elections is pointless since it does not yield any change in how the state is run. Furthermore, the two largest political parties in Croatia are presented as incompetent (or unwilling) to bring about any significant political change. The alternating pyjama colours highlight the futility of the elections, presenting the symbolic overturn whereby the author takes charge of the experience. The absurdity achieved by means of the metaphor undermines the competence and professionalism of the Croatian politicians: the blends undermine their ability to perform political roles, symbolically depriving them of their power and endowing the author with authority instead.

The dying man metaphor is then mixed with the state is a ship metaphor which reinforces the pointlessness of the colors blend and serves as the introduction to the solution of the critical event. The commenter offers an alternative to the current electoral system, where the government should be elected based on an international tender procedure. This resolves the futility of the situation: the choice is no longer between several pyjama colours or two incompetent crews. Rather, the logic of the international tender, where the best bid wins, is employed, which means that in the blend the best possible crew/government will be selected. This sentence is an additional blow in the symbolical act of dispossessing politicians of the power they hold.

${ }^{10}$ Black symbolizes the Croatian Democratic Union - Hrvatska demokratska zajednica (before its reform in 2002), red symbolizes the Social Democratic Party, and blue symbolizes the Croatian Democratic Union (after the reform in 2002). 
The following comment, which describes the so-called fiscalization ${ }^{11}$ exhibits a similar structure.

(6) Vrhunac Linićeve karijere je nesretna fiskalizacija. Projekt je njegovo idejno dijete od početka do kraja. Svakom s malo ekonomske pameti je jasno da je to ideološki komunistički totalno nepotreban sustav nekoristan i dugoročno na 25 godina neisplativ. Kompliciran ultra skup administrativni uteg oko vrata tonuće ekonomije. Uvodjenje kompjutorskog sustava kontrole karata na Titaniku, da se nebi netko švercao molim lijepo dok tonemo. Zaboravite čamce i ispumpavanje vode, karte na pregled! ${ }^{12}$.

'The unfortunate fiscalization is the pinnacle of Linić's career. The project has been his brainchild from the beginning to the end. It is clear to anyone with the slightest knowledge of economy that this is an ideological, communist and completely useless system and, in the long run, in 25 years, unviable. A complicated, super-expensive administrative weight around the neck of a sinking economy. Introduction of a computerized ticket-control system on Titanic so that no one would, god forbid, dodge the fare, while we're sinking. Forget lifeboats and pumping the water out, please have your tickets ready for inspection!'.

The comment begins by describing the critical event - fiscalization as something unnecessary, useless and politically motivated, using literal language. To work through the problem, the commenter turns to figurative expressions: fiscalization as a super-expensive weight around the neck of a sinking economy. The blend is built on the conventional idiomatic expression uteg oko vrata 'weight around the neck', whose literal "administrative super-expensiveness" is an additional burden to the economy, which is sinking anyway. The burden scenario corresponds closely to our knowledge about staying afloat: with the additional super heavy burden, it is almost impossible to do. The sinking economy is then specified as the Titanic, a sinking ship par excellence. The knowledge about fiscalization as a computer system of fiscal control enables its description as computerized ticket control aboard the Titanic. Running the blend ingeniously highlights the declared uselessness of fiscalization: it is an elaborate system to

${ }^{11}$ Cash transactions fiscalization is a set of measures which are used in order to implement an overview of cash transaction revenues where a fiscal software keeps track of each issued receipt. Taken from the web page Fiscalization.hr, <http://www.fiscalization.hr/en>, 12.02.2015.

${ }^{12}$ Taken from the commments section of the article Nakon što se obračunao s premijerom, Linić zasjeo u saborske klupe, "Večernji list" 30.05.2014, <http:/www.vecernji.hr/ hrvatska/nakon-sto-se-obracunao-s-premijerom-linic-zasjeo-u-saborske-klupe-941900>, 9.08.2014. 
avoid dodging the fare while the ship is sinking. The final sentence is the climax of highlighting the faulty logic: presenting tickets for inspection is given priority over activities that could save lives. The futility of having one's tickets inspected in a situation where the ship is sinking is a way to discredit the political efforts of Slavko Linić, showing symbolic power and metaphorically obliterating his endeavour. Furthermore, it is a way of working through one's emotions of disappointment and one's disapproval of the Minister's fiscal law. Unlike the previous commenter, this one does not offer a solution to the problem.

An analysis of all of the comments presented in the results reveals that their structure is similar. In some cases (examples [1], [5] and [6]) the authors begin their exposition by explicitly highlighting the criticality of an event using literal language. This introduction, however, may be left out, and some comments begin with a blend (examples [2], [3] and [4]). The blends, which present the crux of the matter, often proceed from a less intense to a more intense metaphor ${ }^{13}$, exhibiting a narrative-like structure. As metaphors evolve (or blends are run), each step, which builds on the intensity of the previous one, emotionally leads the author through the critical event. The blends rely on symbolically delegitimizing the politicians' actions. This puts the author in charge of the experience, enabling him/her to work through it. In some cases, the commenters offer a remedy to the situation (examples [2] and [5]), whereas in others they do not (examples [1], [3], [4] and [6]). Therefore, deliberate metaphors, in addition to their pragmatic function mentioned by Steen (2014: 180), may also be a way of coming to terms with the emotional significance of a critical event by adopting an alien perspective on a target domain.

${ }^{13}$ This (the fact that you want to work through an event, the fact that you need to express your intensive emotions and get rid of them and show them to others possibly etc.) may be one of the reasons for choosing to mix metaphors (Kimmel 2010) in the first place. In the attempt to envisage an event, to present the feelings it arouses in us, we resort to a diversified pool of knowledge for input spaces since the gradation of thoughts and feelings we want to convey requires metaphors of different intensity (e.g. Titanic is more powerful as a metaphor than the weight metaphor, therefore emotions not evoked/worked through sufficiently good enough by a weight metaphor will be so when depicted by Titanic/by means of a Titanic scenario). 


\section{Discussion and conclusion}

In the comments analyzed in this paper, the commenters did not engage in dialogue with others by posting responses so as to negotiate or question other commenters' metaphors. Instead, they focused on events that they found critical. We argued that this cannot be attributed exclusively to the affordances of the online comments (lack of temporal organization, anonymity), but to a shared emotive element pointing to the futility of the situation, which appeared throughout the metaphorical comments. Although non-dialogic and conceptually unrelated on the surface, the comments were co-constructed, brought together by a common emotional element as well as the act of commenting. We found a common structure in the metaphorical comments, which shows that commenters are working through a critical event. All this points to the therapeutic function of metaphor, which is a tool to explain and work through one's intense emotive situations, and serves only secondarily as a rhetorical means of demonstrating solidarity and/or exerting persuasion ${ }^{14}$. The metaphors allow the commenters to symbolically grasp the reins of a critical event, and thus take charge of their experience. One of the ways of doing so is to blend deliberate metaphors of gradually increasing intensity (cf. De Landtsheer 2009). In this sense, it is the emotional charge that the commenters feel and are attempting to work through that brings about the structure of the blends.

Theoretically, if we take the idea of therapeutic metaphor being structured by emotions seriously, this is yet another piece of evidence for the structural coupling of emotions and metaphors, where they influence each other (Stanojević 2013: 182; Kövecses 2012). Furthermore, the role of emotions in co-constructing and structuring metaphors additionally highlights the difference between conceptual and discursive metaphors, whereby the communicational characteristics of the latter (Steen 2014) go beyond classical turn-taking communication.

This leads to several questions. What is the relation of the therapeutic function of metaphor to its other discursive functions? Do therapeutic

\footnotetext{
${ }^{14}$ This ties in with the role of metaphor as a means of orchestrating change in the counseling process (Robert, Kelly 2010), where (conceptual) metaphor enables making the client aware of their worldview. Still, in such cases metaphors are offered by the counselor to the clients, rather than being emergent.
} 
metaphors occur only in the presence of negative critical events (Delfino, Manca 2007) or can they appear with positive feelings as well? To what extent is therapeutic metaphor different from the ways one can work through one's feelings without using non-literal language? Can therapeutic metaphors appear in other virtual and non-virtual contexts (i.e. counselling sessions, blogs, private spaces) or is therapeutic metaphor limited to comments, because of their affordances (cf. the features of comments in Henrich and Holmes 2013)? Can the features of the public discourse in Croatia and the current political situation in the country be particularly conducive to the therapeutic function of metaphor; i.e. how does therapeutic metaphor vary across cultures and/or other emotive situations?

\section{Literature}

Cap P., 2013, Proximization: The pragmatics of symbolic distance crossing, Amsterdam-Philadelphia.

Cameron L., 2003, Metaphor in educational discourse, London.

Cavalcanti M.C., Bizon A.C., 2008, En Route through Metaphors: Chatrooms as Safe Places to Deal with Difficulties, in: Confronting Metaphor in Use: An Applied Linguistic Approach, ed. M.S. Zanotto, L. Cameron, M.C. Cavalcanti, Amsterdam-Philadelphia, p. 243-65.

Charteris-Black J., 2011, Politicians and rhetoric: the persuasive power of metaphor, Houndmills-Basingstoke-Hampshire-New York.

Delfino M., Manca S., 2007, The expression of social presence through the use of figurative language in a web-based learning environment, "Computers in Human Behavior" no. 5, p. 2190-2211, DOI:10.1016/j.chb.2006.03.001.

De Landtsheer C., 2009, Collecting Political Meaning from the Count of Metaphor, in: Metaphor and Discourse, ed. A. Musolff, J. Zinken, Basingstoke, p. 59-78.

Fauconnier G., Turner M., 2003, The way we think: conceptual blending and the mind's hidden complexities, New York.

Frank R.M., 2008, Introduction:Sociocultural situatedness, in: Body, Language, and Mind, vol. 2, Sociocultural situatedness, ed. R.M. Frank, R. Dirven, T. Ziemke, J. Zlatev, E. Bernárdez, Berlin-New York, p. 1-18.

Geeraerts D., Gevaert C., and Speelman, D., 2011, How anger rose: Hypothesis testing in diachronic semantics, in: Current Methods in Historical Semantics, ed. K. Allan, J.A. Robinson, Berlin-Boston, p. 109-131.

Griffiths P., Scarantino A., 2009, Emotions in the Wild: The Situated Perspective on Emotion, in: The Cambridge Handbook of Situated Cognition, ed. P. Robbins, M. Aydede, New York, p. 473-453. 
Hampel R., 2006, Rethinking task design for the digital age: A framework for language teaching and learning in a synchronous online environment, "ReCALL" no. 1, p. 105-121, DOI:10.1017/S0958344006000711.

Hart C., 2008, Critical discourse analysis and metaphor: toward a theoretical framework, “Critical Discourse Studies" no. 2, p. 91-106, DOI:10.1080/17405900801990058.

Hart C., 2010, Critical Discourse Analysis and Cognitive Science: New Perspectives on Immigration Policies, Basingstoke.

Henrich N., Holmes B., 2013, Web news readers' comments: Towards developing a methodology for using on-line comments in social inquiry, "Journal of Media and Communication Studies" no. 1, p. 1-4, DOI:10.5897/JMCS11.103.

Johnson M., 1993, Moral Imagination: Implications of Cognitive Science for Ethics, Chicago-London.

Kimmel M., 2010, Why we mix metaphors (and mix them well): discourse coherence, conceptual metaphor, and beyond, "Journal of Pragmatics" no. 1, p. 97-115, DOI: 16/j.pragma.2009.05.017.

Koller V., 2005, Critical discourse analysis and social cognition: evidence from business media discourse, "Discourse \& Society" no. 2, p. 199-224, DOI:10.1177/ 0957926505049621.

Koller V., 2013, Metaphern in der Palliativversorgung und Sterbebegleitung, "Leidfaden" no. 2, p. 13-15, DOI: 10.13109/leid.2013.2.3.13.

Kövecses Z., 2000, Metaphor and emotion: language, culture, and body in human feeling, Cambridge-New York.

Kövecses Z., 2012, Emotion concepts in cultural context: the case of happiness, Dynamicity in emotion concepts, ed. P.A. Wilson, Frankfurt am Main-Berlin-Bern-Bruxelles-New York-Oxford-Warszawa-Wien, p. 159-182.

Lakoff G., Johnson M., 1980, Metaphors We Live By, Chicago-London.

Lakoff G., 1993, The contemporary theory of metaphor, in: Metaphor and Thought, ed. A. Ortony, Cambridge, p. 202-251.

Littlemore J., Low G., 2006, Figurative thinking and foreign language learning, Basingstoke-New York.

Manosevitch E., Walker D.M., 2009, Reader Comments to Online Opinion Journalism: A Space of Public Deliberation, Conference paper. 10th International Symposium on Online Journalism, Austin, TX, April 2009, <https://online.journalism. utexas.edu/2009/papers/ManosevitchWalker09.pdf>, 12.02.1015.

Musolff A., 2004, Metaphor and Political Discourse. Analogical Reasoning in Debates about Europe, Basingstoke-New York.

Robert T., Kelly V.A., 2010, Metaphor as an Instrument for Orchestrating Change in Counselor Training and the Counseling Process, "Journal of Counseling \& Development" no.2, p.182-188, DOI:10.1002/j.1556-6678.2010.tb00007.x.

Semino E., 2014, Metaphors at the end of life: results from a large study, Conference paper presented at the 8th World Research Congress of the European Association for Palliative Care (EAPC), Lleida, Spain, < http://ucrel.lancs.ac.uk/melc/ EAPC2014-slides.pdf>, 12.02.2015. 
Stanojević M.-M., 2013, Konceptualna metafora: temeljni pojmovi, teorijski pristupi $i$ metode, Zagreb.

Stanojević M.-M., Ljubičić M., Tralić I., 2014, Grammatical information and conceptual metaphors: the case of anger, in: Language and Information: Proceedings from the CALS conference 2102, ed. M.-M. Stanojević, A. Peti-Satntić, Frankfurt am Main-Berlin-Bern-Bruxelles-New York-Oxford-Wien, p. 131-154.

Steen G., 2008, The paradox of metaphor: why we need a three-dimensional model of metaphor, "Metaphor and Symbol" no. 4, p. 213-241, DOI:10.1080/ 10926480802426753.

Steen G., 2014, Deliberate Metaphor Affords Conscious Metaphorical Cognition, "Cognitive Semiotics" no. 5, p.179-197.

Traugott E.C., 2008, 'All that he endeavoured to prove was...' On the emergence of grammatical constructions in dialogic contexts, in: Language in Flux: Dialogue Coordination, Language Variation, Change and Evolution, ed. R. Cooper, R. Kempson, London, p. 143-177.

Šarić Lj., 2014, Metafora, diskurs i društvo, in: Metafore koje istražujemo: suvremeni uvidi u konceptualnu metaforu, ed. M.-M. Stanojević, Zagreb, p. 169-202.

Verhagen A., 2005, Constructions of intersubjectivity: discourse, syntax, and cognition, Oxford.

Wilce J.M., 2009, Language and Emotion, New York.

Zinken J., Hellsten I., Nerlich B., 2008, Discourse metaphors, in: Body,Language, and Mind. Volume 2: Sociocultural situatedness, ed. R.M. Frank, R. Dirven, T. Ziemke, J. Zlatev, E. Bernárdez, Berlin-New York, p. 363-387.

Zinken J., Musolff A. (ed.), 2009, Metaphor and Discourse, Basingstoke. 